\title{
Identification of determinants of referral and follow-up body mass index of adolescent patients with anorexia nervosa: evidence for the role of premorbid body weight
}

\author{
Johannes Hebebrand
}

Published online: 28 April 2015

(C) Springer-Verlag Berlin Heidelberg 2015

The core symptomatology of anorexia nervosa consists of an intertwining of primary behavioral features and cognitions with mental and physical symptoms related to starvation, which differ depending on age and stage of the disorder $[5,9]$. As such, anorexia nervosa represents a true psychosomatic disorder in the sense that both soma and psyche are affected. Patients restrict their energy intake and/or increase their energy expenditure and as a consequence lose weight. At a more or less early stage of their disorder, they establish an initial contact with medical services, in most cases a pediatrician or general practitioner. In childhood and adolescence, parents or caregivers are frequently the driving force behind this initial presentation; the young patients themselves are often reluctant to seek medical help. In single cases, teachers, friends and relatives of the patient may be crucial for the initiation of help seeking behavior by persuading the patient and her caregivers to contact a physician. However, when queried accordingly, some patients do admit that their mood and their concentration have deteriorated and that they no longer have the drive to pursue social contacts. They often also to some extent agree that somatic symptoms such as loss of hair, pallor, sleep disturbances, increased cold sensitivity, and a reduced fitness are worrisome; in contrast, one of the four cardinal DSM-IV symptoms, namely amenorrhea, is frequently not mentioned as a complaint. The parents are mostly worried by the aberrant eating behavior, recent weight loss and the ensuing underweight; they may also seek help because of hyperactivity or depressed mood

J. Hebebrand $(\bowtie)$

Department of Child and Adolescent Psychiatry, Psychosomatics and Psychotherapy, LVR Klinikum Essen, Universitätsklinikum Essen, University of Duisburg-Essen, Wickenburgerstr. 21, 45147 Essen, Germany

e-mail: Johannes.Hebebrand@uni-due.de and irritability of their daughters; still others are worried by their daughters' anhedonia, perfectionism and rigidity. Depending on education level and the interrelated medical knowledge they are also concerned with potential longer term somatic problems that may result from anorexia nervosa; examples include infertility and osteoporosis.

This conglomeration of frequent and infrequent complaints is brought forward upon the initial contact with medical services. In contrast to some decades ago, nowadays many more physicians are knowledgeable about the eating disorder and as a consequence are likely to more or less rapidly refer to a specialist. This may be a reason underlying the observation of a secular trend towards a higher BMI at referral [2]. Obviously, diagnosis can be tricky if patients and parents bring forward less frequent complaints and do not mention weight loss; in addition, the underweight may not be readily discernible either because it is not severe enough to readily merit attention or it is in some way concealed by the patient.

Either the initially contacted physician or the specialist may refer the patient for inpatient treatment if the health of the patient is acutely compromised by for instance a low body mass index (BMI; e.g. $<14 \mathrm{~kg} / \mathrm{m}^{2}$ ), reduced fluid intake, continuous weight loss, complete lack of food intake, failure to gain weight on an outpatient basis, serious comorbid psychiatric or somatic disorders including severe depression, suicidality, bradycardia and hypothermia. In many cases, however, inpatient treatment is not initiated immediately after the physician has deemed it necessary. The patients and their parents need to find a suitable treatment center, which provides a specialized outpatient- and if necessary inpatient-treatment program; this facility must be in a position to admit the patient. Frequently, the patient's reluctance to start inpatient treatment in combination with parental incertitude also entails a further delay. 
Can we identify factors that predict at what BMI patients are admitted for inpatient treatment? Upon acknowledgement of the complexity of the aforementioned issues and decision processes this would seem rather improbable. Surprisingly, however, a single factor, namely premorbid BMI, explains approximately $20-35 \%$ of the variance of the BMI at admission. Coners et al. [3] initially found a rather strong correlation in the magnitude of $r=0.6$ between premorbid BMI age percentile and referral BMI among 42 adolescent patients with anorexia nervosa. This correlation may actually even have been underestimated somewhat, because the premorbid BMI was merely estimated based on self-recalled premorbid weight and height measured upon referral. Take for instance a patient whose disease duration lasted 1.5 years prior to referral. Whereas the patient's obsession with weight may indeed frequently allow her to correctly recall her weight directly prior to the initial weight loss, this does not hold true for body height. To analyze to what extent results are dependent on the use of measured current height-a procedure which systematically under estimates BMI at onset of the eating disorder due to a potentially too high denominator in $\mathrm{kg} / \mathrm{m}^{2}$ in still growing young females-Coners et al. also estimated individual height prior to the onset of the eating disorder by subtracting the mean increment in height between age at onset of anorexia nervosa from measured height at referral to then recalculate premorbid BMI. Overall, the results were very similar; again approximately $35 \%$ of the BMI variation at referral was explained by premorbid BMI percentile.

Interestingly and in contrast to the effect of premorbid body weight adjusted for age and height, the duration of the eating disorder prior to referral did not explain variation of the BMI at referral. Stated specifically, a longer duration of the eating disorder was not associated with a lower BMI at referral of these adolescent patients. Age in itself also did not significantly affect BMI at referral. In additional analyses, the investigators also found a rather strong correlation for total weight loss in $\mathrm{kg} / \mathrm{m}^{2}$ during the duration of the eating disorder and BMI at referral for inpatient treatment: the higher the weight loss, the higher the BMI at referral. Finally, it should be pointed out that based on this limited number of patients, the average relative premorbid weight was not skewed towards the underweight or overweight range, suggesting that anorexia nervosa can affect females of any body weight with a similar probability.

These initial results have been repeatedly confirmed $[6,13,15]$. Different statistical approaches were used within these confirmatory studies. Miyasaka et al. split their sample based on a premorbid BMI $<20.5$ or $\geq 20.5 \mathrm{~kg} / \mathrm{m}^{2}$ and found a difference of $1.1 \mathrm{~kg} / \mathrm{m}^{2}$ for the BMI at referral between the two groups $(14.4 \pm 1.7$ versus $15.5 \pm 1.8 \mathrm{~kg} / \mathrm{m}^{2}$ ). Because of this confirmation in this
Japanese sample, the effect of premorbid BMI on BMI at referral is seemingly independent of ethnic background. Steinhausen et al. [15] used a logistic regression model to confirm the predictive value of premorbid BMI for BMI at referral in a large sample of 212 young patients with anorexia nervosa (mean age: $15.0 \pm 2.7$ years). The correlation coefficient between premorbid BMI and BMI at first admission was $r=0.5$. While a direct comparison of this coefficient with that detected by Coners et al. is not possible (use of premorbid age percentile for BMI versus premorbid BMI), the magnitude of the correlation appears quite similar.

Most recently, Föcker et al. [6] used a multivariate statistical model including the independent variables age, duration of illness, duration of treatment, BMI at admission and BMI percentile at discharge in their analysis based on 161 patients of the (see [10], for a detailed description of the patient sample) with a mean age of $15.2 \pm 1.5$ years. Again, the relationship between premorbid BMI percentile and BMI at admission was solidly confirmed. The correlation between premorbid BMI percentile and BMI at referral was 0.45. In addition to premorbid BMI percentile, BMI at admission and age were significant predictors of BMI percentile at discharge. Furthermore, BMI percentile at discharge significantly predicted BMI percentile at 1-year follow-up. An additional analysis that merely included variables available upon referral revealed that premorbid BMI percentile predicted the 1-year follow-up BMI percentile. Steinhausen et al. had previously shown that premorbid BMI predicts BMI after a mean follow-up of 8.3 years $(r=0.2)$.

Several issues with respect to the predictive value of premorbid body weight for BMI at referral, discharge and follow-up warrant consideration:

1. It appears that premorbid overweight has a beneficial effect on the weight course of patients with anorexia nervosa. Upon admission their BMI is not as low as that of their premorbidly underweight counterparts. In addition, the premorbid overweight entails a higher BMI at discharge and at follow-up. It should be noted that this positive prognostic factor applies to body weight development-it is currently unclear if it entails a better overall prognosis including factors such as psychosocial adjustment and psychiatric comorbidity. It has, for example, been known for a longer period of time that childhood obesity and a positive family history for obesity entail a higher risk for the development of bulimia nervosa $[4,8]$; accordingly, the initially overweight patients likely also have an elevated risk of developing bulimia nervosa after they no longer are underweight. Studies are required to assess differences in temperament, personality and both lifetime and comorbid psychiatric disorders in patients with 
anorexia nervosa in relationship to premorbid weight category. Furthermore, it is of interest to determine if premorbid obesity and in particular extreme obesity are incompatible with the development of anorexia nervosa during adolescence. Such subjects may not reach the underweight range required for a diagnosis of full blown anorexia nervosa.

2. In pathophysiological terms, it appears that anorexia nervosa does not totally override the mechanisms that apply to body weight regulation in healthy individuals. Thus, tracking of BMI is well known-the shorter apart the time period between initial and follow-up measurements the higher the tracking as assessed by the magnitude of the BMI correlation. Because among adolescent females tracking is high over a 1- to 3-year period, the mere correlation of about $r=0.5$ between premorbid BMI and BMI at referral is substantially lower than that to be expected for healthy individuals followed up within a 1- to 2-year period. For example, 3-year BMI correlations for boys and girls aged 9 at initial assessment were $>0.8$ in a study of US children [12].

3. Genetic factors figure prominently in BMI tracking [14] and in body weight regulation in general. The number of genes involved in regulation of BMI has increased as delineated in the most recent large-scale meta-analysis of genome-wide association studies [11]; the studies showing tracking of premorbid BMI and BMI at referral suggest that genes involved in body weight regulation of healthy adolescents also-albeit to a lesser extent - explain variation of BMI at referral of young patients with anorexia nervosa. Alleles of the respective BMI loci may not only contribute to anthropometric characteristics, but also to psychopathological features commonly encountered in patients with eating disorders [7]. Due to the low effect sizes of genetic factors involved in body weight regulation, information on $\mathrm{BMI}$ at referral of many patients would be required to indeed prove their effect on BMI at referral. However, due to the fact that (only) 97 genes were identified in the most recent meta-analysis for BMI [11], $p$ values need not to be adjusted for a genome-wide analysis. As such, the hypothesis can be tested based on currently available genome-wide association data of patients with anorexia nervosa [1].

4. Because BMI is a composite measure for both heightadjusted fat and fat-free mass, we need to assess if the determination of absolute fat mass, percent body fat mass or fat mass adjusted for height $\left(\mathrm{kg} / \mathrm{m}^{2}\right)$ at referral (unfortunately, a determination of premorbid body composition is not a realistic scenario) results in a higher correlation with height- and age-adjusted premorbid body weight. If premorbid BMI better pre- dicts fat mass (and fat-free mass) at referral than BMI, this would more specifically enable the assessment of genetic, endocrine and environmental parameters involved in the tracking observed in anorexia nervosa.

5. Currently, we do not know if the tracking observed in adolescent patients also holds true for adult patients. A similar analysis of patients with late onset anorexia nervosa is warranted. Because the duration of the eating disorder is typically not that long in adolescents, adult patients should optimally be subdivided into those with a short and long (chronic) duration of anorexia nervosa.

6. Finally, considering the clinical variability of the time point for initiation of inpatient treatment it would prove valuable to identify other predictors of BMI at referral apart from premorbid BMI. Such information could prove valuable for early identification of patients at risk for a low BMI. In addition, such variables may also allow prediction of the medium- and long-term outcome.

\section{References}

1. Boraska V, Franklin CS, Floyd JA, Thornton LM, Huckins LM, Southam L, Rayner NW, Tachmazidou I, Klump KL, Treasure J, Lewis CM, Schmidt U, Tozzi F, Kiezebrink K, Hebebrand J, Gorwood P, Adan RA, Kas MJ, Favaro A, Santonastaso P, FernándezAranda F, Gratacos MH, Rybakowski F, Dmitrzak-Weglarz M, Kaprio J, Keski-Rahkonen A, Raevuori A, Van Furth EF, Slof-Op 't Landt MC, Hudson JI, Reichborn-Kjennerud T, Knudsen GP, Monteleone P, Kaplan AS, Karwautz A, Hakonarson H, Berrettini WH, Guo Y, Li D, Schork NJ, Komaki G, Ando T, Inoko H, Esko T, Fischer K, Männik K, Metspalu A, Baker JH, Cone RD, Dackor J, DeSocio JE, Hilliard CE, O'Toole JK, Pantel J, Szatkiewicz JP, Taico C, Zerwas S, Trace SE, Davis OS, Helder S, Bühren K, Burghardt R, de Zwaan M, Egberts K, Ehrlich S, Herpertz-Dahlmann B, Herzog W, Imgart HH, Scherag A, Scherag S, Zipfel S, Boni C, Ramoz N, Versini A, Brandys MK, Danner UN, de Kovel C, Hendriks J, Koeleman BP, Ophoff RA, Strengman E, van Elburg AA, Bruson AH, Clementi M, Degortes D, Forzan M, Tenconi E, Docampo E, Escaramís G, Jiménez-Murcia S, Lissowska J, Rajewski A, Szeszenia-Dabrowska N, Slopien A, Hauser J, Karhunen L, Meulenbelt I, Slagboom PE, Tortorella A, Maj M, Dedoussis G, Dikeos D, Gonidakis F, Tziouvas K, Tsitsika A, Papezova H, Slachtova L, Martaskova D, Kennedy JL, Levitan RD, Yilmaz Z, Huemer J, Koubek D, Merl E, Wagner G, Lichtenstein P, Breen G, Cohen-Woods S, Farmer A, McGuffin P, Cichon S, Giegling I, Herms S, Rujescu D, Schreiber S, Wichmann HE, Dina C, Sladek R, Gambaro G, Soranzo N, Julia A, Marsal S, Rabionet R, Gaborieau V, Dick DM, Palotie A, Ripatti S, Widén E, Andreassen OA, Espeseth T, Lundervold A, Reinvang I, Steen VM, Le Hellard S, Mattingsdal M, Ntalla I, Bencko V, Foretova L, Janout V, Navratilova M, Gallinger S, Pinto D, Scherer SW, Aschauer H, Carlberg L, Schosser A, Alfredsson L, Ding B, Klareskog L, Padyukov L, Courtet P, Guillaume S, Jaussent I, Finan C, Kalsi G, Roberts M, Logan DW, Peltonen L, Ritchie GR, Barrett JC, Wellcome Trust Case Control Consortium 3, Estivill X, Hinney A, Sullivan PF, Collier DA, Zeggini E, Bulik CM (2014) A genome-wide association study of anorexia nervosa. Mol Psychiatry 19(10):1085-1094 
2. Buhren K, von Ribbeck L, Schwarte R, Egberts K, Pfeiffer E, Fleischhaker C, Wewetzer C, Kennes LN, Dempfle A, HerpertzDahlmann B (2013) Body mass index in adolescent anorexia nervosa patients in relation to age, time point and site of admission. Eur Child Adolesc Psychiatry 22(7):395-400

3. Coners H, Remschmidt H, Hebebrand J (1999) The relationship between premorbid body weight, weight loss, and weight at referral in adolescent patients with anorexia nervosa. Int J Eat Disord 26(2):171-178

4. Fairburn CG, Welch SL, Doll HA et al (1997) Risk factors for bulimia nervosa. A community based case-control study. Arch Gen Psychiatry 54(6):509-517

5. Föcker M, Knoll S, Hebebrand J (2013) Anorexia nervosa. Eur Child Adolesc Psychiatry 22(Suppl 1):S29-S35. doi:10.1007/ s00787-012-0358-6

6. Föcker M, Bühren K, Timmesfeld N, Dempfle A, Knoll S, Schwarte R, Egberts KM, Pfeiffer E, Fleischhaker C, Wewetzer C, Hebebrand J, Herpertz-Dahlmann B The relationship between premorbid body weight and weight at referral, at discharge and at 1-year follow-up in anorexia nervosa. Eur Child Adolesc Psychiatry, this issue

7. Gamero-Villarroel C, Gordillo I, Carrillo JA, Garcia-Herraiz A, Flores I, Jimenez M, Monge M, Rodriguez-Lopez R, Gervasini G (2014) BDNF genetic variability modulates psychopathological symptoms in patients with eating disorders. Eur Child Adolesc Psychiatry 23(8):669-679

8. Hebebrand J (2009) Diagnostic issues in eating disorders and obesity. Child Adolesc Psychiatr Clin N Am 18(1):1-16

9. Hebebrand J, Bulik CM (2011) Critical appraisal of the provisional DSM-5 criteria for anorexia nervosa and an alternative proposal. Int J Eat Disord 44(8):665-678

10. Herpertz-Dahlmann B, Schwarte R, Krei M, Egberts K, Warnke A, Wewetzer C, Pfeiffer E, Fleischhaker C, Scherag A, Holtkamp K, Hagenah U, Bühren K, Konrad K, Schmidt U, SchadeBrittinger C, Timmesfeld N, Dempfle A (2014) Day-patient treatment after short inpatient care versus continued inpatient treatment in adolescents with anorexia nervosa (ANDI): a multicentre, randomised, open-label, non-inferiority trial. Lancet 383(9924):1222-1229

11. Locke AE, Kahali B, Berndt SI, Justice AE, Pers TH, Day FR, Powell C, Vedantam S, Buchkovich ML, Yang J, Croteau-Chonka DC, Esko T, Fall T, Ferreira T, Gustafsson S, Kutalik Z, Luan J, Mägi R, Randall JC, Winkler TW, Wood AR, Workalemahu T, Faul JD, Smith JA, Hua Zhao J, Zhao W, Chen J, Fehrmann R, Hedman AK, Karjalainen J, Schmidt EM, Absher D, Amin N, Anderson D, Beekman M, Bolton JL, Bragg-Gresham JL, Buyske S, Demirkan A, Deng G, Ehret GB, Feenstra B, Feitosa MF, Fischer K, Goel A, Gong J, Jackson AU, Kanoni S, Kleber ME, Kristiansson K, Lim U, Lotay V, Mangino M, Mateo Leach I, Medina-Gomez C, Medland SE, Nalls MA, Palmer CD, Pasko D, Pechlivanis S, Peters MJ, Prokopenko I, Shungin D, Stančáková A, Strawbridge RJ, Ju Sung Y, Tanaka T, Teumer A, Trompet S, van der Laan SW, van Setten J, Van Vliet-Ostaptchouk JV, Wang Z, Yengo L, Zhang W, Isaacs A, Albrecht E, Ärnlöv J, Arscott GM, Attwood AP, Bandinelli S, Barrett A, Bas IN, Bellis C, Bennett AJ, Berne C, Blagieva R, Blüher M, Böhringer S, Bonnycastle LL, Böttcher Y, Boyd HA, Bruinenberg M, Caspersen IH, Ida Chen YD, Clarke R, Daw EW, de Craen AJ, Delgado G, Dimitriou M, Doney AS, Eklund N, Estrada K, Eury E, Folkersen L, Fraser RM, Garcia ME, Geller F, Giedraitis V, Gigante B, Go AS, Golay A, Goodall AH, Gordon SD, Gorski M, Grabe HJ, Grallert H, Grammer TB, Gräßler J, Grönberg H, Groves CJ, Gusto G, Haessler J, Hall P, Haller T, Hallmans G, Hartman CA, Hassinen M, Hayward C, Heard-Costa NL, Helmer Q, Hengstenberg C, Holmen O, Hottenga JJ, James AL, Jeff JM, Johansson A, Jolley J, Juliusdottir T, Kinnunen L, Koenig W, Koskenvuo M, Kratzer
W, Laitinen J, Lamina C, Leander K, Lee NR, Lichtner P, Lind L, Lindström J, Sin Lo K, Lobbens S, Lorbeer R, Lu Y, Mach F, Magnusson PK, Mahajan A, McArdle WL, McLachlan S, Menni C, Merger S, Mihailov E, Milani L, Moayyeri A, Monda KL, Morken MA, Mulas A, Müller G, Müller-Nurasyid M, Musk AW, Nagaraja R, Nöthen MM, Nolte IM, Pilz S, Rayner NW, Renstrom F, Rettig R, Ried JS, Ripke S, Robertson NR, Rose LM, Sanna S, Scharnagl H, Scholtens S, Schumacher FR, Scott WR, Seufferlein T, Shi J, Vernon Smith A, Smolonska J, Stanton AV, Steinthorsdottir V, Stirrups K, Stringham HM, Sundström J, Swertz MA, Swift AJ, Syvänen AC, Tan ST, Tayo BO, Thorand B, Thorleifsson G, Tyrer JP, Uh HW, Vandenput L, Verhulst FC, Vermeulen SH, Verweij N, Vonk JM, Waite LL, Warren HR, Waterworth D, Weedon MN, Wilkens LR, Willenborg C, Wilsgaard T, Wojczynski MK, Wong A, Wright AF, Zhang Q, LifeLines Cohort Study, Brennan EP, Choi M, Dastani Z, Drong AW, Eriksson P, Franco-Cereceda A, Gådin JR, Gharavi AG, Goddard ME, Handsaker RE, Huang J, Karpe F, Kathiresan S, Keildson S, Kiryluk K, Kubo M, Lee JY, Liang L, Lifton RP, Ma B, McCarroll SA, McKnight AJ, Min JL, Moffatt MF, Montgomery GW, Murabito JM, Nicholson G, Nyholt DR, Okada Y, Perry JR, Dorajoo R, Reinmaa E, Salem RM, Sandholm N, Scott RA, Stolk L, Takahashi A, Tanaka T, Van't Hooft FM, Vinkhuyzen AA, Westra HJ, Zheng W, Zondervan KT, ADIPOGen Consortium, AGEN-BMI Working Group, CARDIOGRAMplusC4D Consortium, CKDGen Consortium, GLGC, ICBP, MAGIC Investigators, MuTHER Consortium, MIGen Consortium, PAGE Consortium, ReproGen Consortium, GENIE Consortium, International Endogene Consortium, Heath AC, Arveiler D, Bakker SJ, Beilby J, Bergman RN, Blangero J, Bovet P, Campbell H, Caulfield MJ, Cesana G, Chakravarti A, Chasman DI, Chines PS, Collins FS, Crawford DC, Cupples LA, Cusi D, Danesh J, de Faire U, den Ruijter HM, Dominiczak AF, Erbel R, Erdmann J, Eriksson JG, Farrall M, Felix SB, Ferrannini E, Ferrières J, Ford I, Forouhi NG, Forrester T, Franco OH, Gansevoort RT, Gejman PV, Gieger C, Gottesman O, Gudnason V, Gyllensten U, Hall AS, Harris TB, Hattersley AT, Hicks AA, Hindorff LA, Hingorani AD, Hofman A, Homuth G, Hovingh GK, Humphries SE, Hunt SC, Hyppönen E, Illig T, Jacobs KB, Jarvelin MR, Jöckel KH, Johansen B, Jousilahti P, Jukema JW, Jula AM, Kaprio J, Kastelein JJ, Keinanen-Kiukaanniemi SM, Kiemeney LA, Knekt P, Kooner JS, Kooperberg C, Kovacs P, Kraja AT, Kumari M, Kuusisto J, Lakka TA, Langenberg C, Le Marchand L, Lehtimäki T, Lyssenko V, Männistö S, Marette A, Matise TC, McKenzie CA, McKnight B, Moll FL, Morris AD, Morris AP, Murray JC, Nelis M, Ohlsson C, Oldehinkel AJ, Ong KK, Madden PA, Pasterkamp G, Peden JF, Peters A, Postma DS, Pramstaller PP, Price JF, Qi L, Raitakari OT, Rankinen T, Rao DC, Rice TK, Ridker PM, Rioux JD, Ritchie MD, Rudan I, Salomaa V, Samani NJ, Saramies J, Sarzynski MA, Schunkert H, Schwarz PE, Sever P, Shuldiner AR, Sinisalo J, Stolk RP, Strauch K, Tönjes A, Trégouët DA, Tremblay A, Tremoli E, Virtamo J, Vohl MC, Völker U, Waeber G, Willemsen G, Witteman JC, Zillikens MC, Adair LS, Amouyel P, Asselbergs FW, Assimes TL, Bochud M, Boehm BO, Boerwinkle E, Bornstein SR, Bottinger EP, Bouchard C, Cauchi S, Chambers JC, Chanock SJ, Cooper RS, de Bakker PI, Dedoussis G, Ferrucci L, Franks PW, Froguel P, Groop LC, Haiman CA, Hamsten A, Hui J, Hunter DJ, Hveem K, Kaplan RC, Kivimaki M, Kuh D, Laakso M, Liu Y, Martin NG, März W, Melbye M, Metspalu A, Moebus S, Munroe PB, Njølstad I, Oostra BA, Palmer CN, Pedersen NL, Perola M, Pérusse L, Peters U, Power C, Quertermous T, Rauramaa R, Rivadeneira F, Saaristo TE, Saleheen D, Sattar N, Schadt EE, Schlessinger D, Slagboom PE, Snieder H, Spector TD, Thorsteinsdottir U, Stumvoll M, Tuomilehto J, Uitterlinden AG, Uusitupa M, van der Harst P, Walker M, Wallaschofski H, Wareham NJ, Watkins H, Weir DR, Wichmann HE, Wilson JF, 
Zanen P, Borecki IB, Deloukas P, Fox CS, Heid IM, O’Connell JR, Strachan DP, Stefansson K, van Duijn CM, Abecasis GR, Franke L, Frayling TM, McCarthy MI, Visscher PM, Scherag A, Willer CJ, Boehnke M, Mohlke KL, Lindgren CM, Beckmann JS, Barroso I, North KE, Ingelsson E, Hirschhorn JN, Loos RJ, Speliotes EK (2015) Genetic studies of body mass index yield new insights for obesity biology. Nature 518(7538):197-206

12. Marshall SJ, Sarkin JA, Sallis JF, McKenzie TL (1998) Tracking of health-related fitness components in youth ages 9 to 12. Med Sci Sports Exerc 30(6):910-916

13. Miyasaka N, Yoshiuchi K, Yamanaka G, Sasaki T, Kumano H, Kuboki T (2003) Relations among premorbid weight, referral weight, and psychological test scores for patients with anorexia nervosa. Psychol Rep 92(1):67-74

14. Silventoinen K, Kaprio J (2009) Genetics of tracking of body mass index from birth to late middle age: evidence from twin and family studies. Obes Facts 2(3):196-202

15. Steinhausen HC, Grigoroiu-Serbanescu M, Boyadjieva S, Neumärker KJ, Metzke CW (2009) The relevance of body weight in the medium-term to long-term course of adolescent anorexia nervosa. Findings from a multisite study. Int J Eat Disord 42(1):19-25 